\title{
Evaluasi Proses Bisnis Akademik STIKOM Dinamika Bangsa Melalui Pendekatan Business Process Improvement
}

\author{
$\underline{\text { Akwan Sunoto }}$ \\ Sistem Informasi, Ilmu Komputer, Universitas Dinamika Bangsa \\ Jl.Jenderal Sudirman Thehok, Jambi, Indonesia \\ akwan@stikom-db.ac.id
}

\begin{abstract}
STIKOM Dinamika Bangsa is a computer science college but not all activities in its academic business process are supported by the use of information technology so that the business process does not run optimally. There are several obstacles emerging in the academic business process such as the length of the process, the convoluted activity and the length of the activity processed so that the activity does not run effectively. Therefore this academic business process needs to be analyzed and evaluated. In this study, the evaluation was conducted through the Business Process Improvement (BPI) approach while modeling the business process using Business Process Modelling Notation (BPMN). This research activity resulted in modeling and improvement recommendations on the activities contained in each business process so that the effectiveness and efficiency of business processes can be improved.
\end{abstract}

Keywords : Business process improvment, business processes evaluation, modeling

\begin{abstract}
Abstrak
STIKOM Dinamika Bangsa adalah satu perguruan tinggi bidang ilmu komputer namun belum semua aktivitas dalam proses bisnis akademiknya didukung dengan penggunaan teknologi informasi sehingga proses bisnisnya tidak berjalan optimal. Ada beberapa kendala muncul dalam proses bisnis akademiknya seperti panjangnya proses yang dilalui, aktivitas yang berbelit serta lamanya aktivitas diproses sehingga aktivitas tidak berjalan efektif. Oleh karena itu proses bisnis akademik ini perlu dianalisis dan dievaluasi. Dalam penelitian ini evaluasi dilakukan melalui pendekatan Business Process Improvement (BPI) sedangkan pemodelan proses bisnisnya menggunakan Business Process Modelling Notation (BPMN). Kegiatan penelitian ini menghasilkan pemodelan serta rekomendasi-rekomendasi perbaikan terhadap aktivitas-aktivitas yang terdapat didalam masing-masing proses bisnis sehingga efektivitas dan efisiensi dari proses bisnis dapat di tingkatkan.
\end{abstract}

Kata Kunci : business process improvement, evaluasi proses bisnis, pemodelan

\section{Pendahuluan}

STIKOM Dinamika Bangsa Selaku selaku perguruan Tinggi dibidang komputer tentu seharusnya aktivitas proses bisnisnya sudah didukung penuh dengan penggunaan Teknologi Informasi, akan tetapi pada kenyataannya masih terdapat proses bisnis yang belum menyeluruh menggunakan Teknolofi Informasi khusus pada bidang layanan akademik. Seperti pendaftaran calon Mahasiswa baru, Registrasi ulang Mahasiswa baru, pendaftaran ulang mahasiswa, pengajuan cuti kuliah, pendaftaran Skripsi, pendaftaran ujian labor dan sidang skripsi serta pendaftaran wisuda.Masih ditemui beberapa kendala proses bisnis akademiknya seperti panjangnya proses yang dilalui, aktivitas yang berbelit serta lamanya aktivitas diproses sehingga aktivitas tidak berjalan efektif. Mengingat pentingnya proses bisnis bagi kelangsungan organisasi maka proses bisnis akademik di STIKOM Dinamika Bangsa perlu dilakukan evaluasi serta pemodelan untuk menghasilkan rekomendasi-rekomendasi perbaikan proses bisnis sehingga efektivitas dan efisiensi proses bisnis dapat ditingkatkan.

Untuk mengetahui seberapa jauh efektivitas proses bisnis yang berjalan di proses layanan akademik di STIKOM Dinamika Bangsa maka perlu dilakukan evaluasi dan pemodelan terhadap proses bisnis yang ada. Dalam penelitian ini evaluasi dan pemodelan proses bisnis dilakukan melalui pendekatan Business Process Improvement (BPI) dan Business Process Modelling Notation (BPMN). Tujuan dari penggunaan 
metode BPI adalah untuk mendapatkan solusi permasalahan dari proses bisnis saat ini. Hasil dari penggunaan BPI ini berupa rekomendasi proses bisnis baru dengan mengubah proses seperti meminimalkan penundaan suatu proses bisnis, memaksimalkan penggunaan aset, memberikan pemahaman, meminimalisir SDM yang ada maupun biaya dari pengeluaran yang berlebih.

Kegiatan suatu organisasi dapat berjalan dengan optimal bila didukung oleh proses bisnis yang tepat, oleh karena itu pemodelan proses bisnis menjadi hal yang sangat penting untuk mengetahui proses bisnis mana saja yang sudah mencapai target serta proses bisnis mana yang memerlukan perbaikan [1].

Kompleksitas suatu proses bisnis membuat membuat perusahaan mencari cara untuk menggambarkan danmengevaluasi proses proses bisnis untuk melakukan perbaikan proses bisnis di masa mendatang [2]. Jika proses bisnis berjalan baik maka kegiatan operasional akan berjalan lebih efisien dan efektif [3]. Oleh karena itu proses bisnis yang ada dalam organisasi perlu di anaslis dan dievaluasi untuk mengetahui apakah masih diperlukan peningkatan proses bisnis.

Salah satu langkah yang dapat dilakukan untuk memahami serta mengevaluasi proses bisnis yaitu melalui pemodelan. Melalui pemodelan kita dapat memahami, menganalisa, mendesain serta melakukan evaluasi dan merekomendasikan perbaikan proses bisnis dimasa mendatang. Pemodelan proses bisnis yang baik akandapat meningkatkan kinerja organisasi secara keseluruhan dan kepuasan pelakuorganisasi [4].

Pengukuran kinerja dari proses bisnis dapat dilakukan dengan melakukan simulasi terhadap proses bisnis. Simulasi dilakukan untuk mengetahui dan menghilangkan hambatan yang tak terduga, mengetahui dan mengurangi resiko, mencegah kekurangan ataupun kelebihan dari penggunaan sumber daya termasuk manusia dan biaya, kegagalan model, serta untuk mengoptimalkan kinerja sistem [5].

Business process improvement merupakan salah satu cara yang dapat digunakan oleh organisasi atau perusahaandalam membuat kemajuan yang signifikan dalam pelaksanaan proses bisnisnya[6].BPI juga merupakanmetode sistematik yang dikembangkan untuk membantu organisasi membuat suatu peningkatanyang signifikan melalui cara proses bisnisnya beroperasi [7]. Dengan metode BPI dapat disusun kerangka sistematis yang dapat membantu organisasi untuk membuat kemajuan yang signifikan dalam pelaksanaan proses bisnisnya [8].

\section{Metodologi}

Agar penelitian dapat berjalan dengan baik maka harus disusun dahulu kerangka kerangka kerja penelitiannya. Kerangka kerja ini merupakan urutan langkah-langkah kerja didalam penyelesaian penelitian yang dapat dilihat pada gambar berikut:

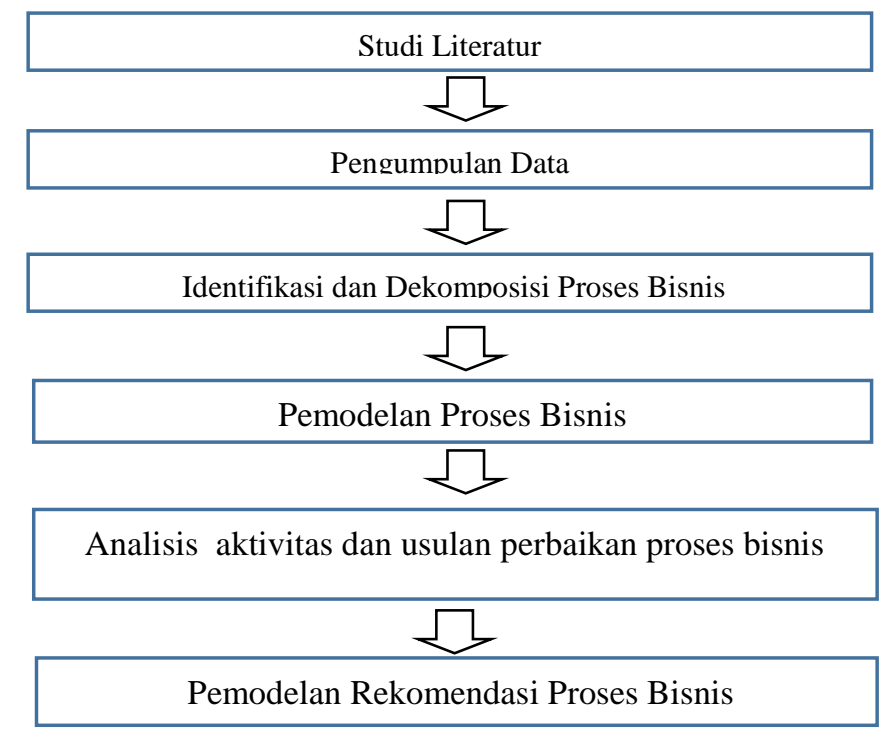

Gambar 1: Kerangka Kerja Penelitian 
1. Penelitian ini dimulai dengan mencari literatur-literatur yang berkaitan dengan tema penelitian sehingga didapatkan landasan-landasan keilmuan yang kuat dalam melaksanakan penelitian ini.

2. Langkah kedua adalah melakukan pengumpulan data-data yang berkaitan dengan proses bisnis akademik di STIKOM Dinamika Bangsa dengan cara observasi serta mempelajari dokumendokumen yang berkaitan dengan aktivitas proses bisnis sehingga didapatkan pemahaman yang baik terhadap proses bisnis yang ada. Observasi dilakukan dengan melibatkan pihak-pihak yang terlibat dalam proses bisnis seperti mahasiswa, dosen pembimbing akademik, program studi, BAAK, Front Office dan BAU. Sedangkan dokumen yang yang dikumpulkan berupa prosedurprosedur yang berlaku untuk semua proses bisnis.

3. Langkah ketiga adalah melakukan identifikasi proses bisnis untuk memetakan proses bisnis utama dan proses bisnis pendukung. Tool yang digunakan pada tahap ini adalah value chain analisis. Pada penelitian ini fokus utamanya adalah proses bisnis pada pelayanan administrasi akademik.

4. Langkah keempat adalah dengan melakukan pemodelan terhadap proses bisnis yang telah ditentukan. Dalam penelitian ini untuk pemodelan proses bisnis menggunakan Business Process Modelling Notation (BPMN). BPMN berfungsi menyediakan representasi grafis untuk menentukan proses bisnis dalam suatu pemodelan proses bisnis [9].Tujuan yang paling utama dari BPMN adalah untuk menyediakan sebuah standar notasi yang mudah di mengerti oleh semua pelaku bisnis [1].Kelebihan dari BPMN yaitu dapat menggambarkan proses bisnis secara detail dengan aliran informasi berupa pesan yang disampaikan antar pihak terkait terutama dalam perusahaan [10].Kegiatan ini bertujuan untuk mengetahui seperti apa proses bisnis yang saat ini berjalan sekaligus untuk mengetahui kendala dan permasalahan yang terdapat di masingmasing aktivitas pada proses bisnis

5. Langkah ke lima adalah melakukan Analisis aktivitas dan usulan perbaikan proses bisnis. Langkah ini dilakukan dengan cara melakukan eliminasi Kegiatan Non Value added (NVA). NVA merupakan aktivitas dari suatu proses bisnis yang tidak memberikan keuntungan dan nilai yang berarti kepada pelanggan maupun dalam proses bisnis sehingga dengan melakukan pengeliminasian aktivitas ini dapat memberikan efisiensi waktu pada proses bisnis organisasi. contoh: Redundant inspections, Filling in forms, Rework, Excessive transit, Waiting, Storage.Selanjut ya Meminimalisir kegiatan Business Value Added(BVA). BVA merupakan aktivitas-aktivitas dari suatu proses bisnis yang tidak memberikan nilai tambah bagi hasil dari proses secara langsung, tetapi aktivitas ini diperlukan dalam proses bisnis sebagai pendukung untuk proses bisnis lainnya sehingga dengan adanya aktivitas ini dapat membantu proses menjadi lebih efektif namun aktivitas ini tidak dianjurkan untuk berlebihan sehingga membutuhkan pengurangan pada proses ini. contoh: Scheduling, Marketing, planning,Auditing.Dan yang terakhir mederhanakankegiatanReal Value Added(RVA). RVA mencakup proses penting yang mengubah input menjadi output yang diperlukan untuk memenuhi kepuasan pelanggan sehingga proses ini menjadi sangat penting namun semakin sederhana aktivitas ini semakin baik dalam keefektivitasan dan keefisiensian siklus waktu. contoh : Product development, Material procurement [7].

6. Langkah yang terakhir adalah melakukan pemodelan terhadap proses bisnis yang akan di rekomendasikan.Pada tahap ini dilakukan penyederhanaan proses bisnis dengan dengan tujuan peningkatan efektivitas dan efisiensi dan adaptabilitas dari suatu proses bisnis.

\section{Hasil dan Pembahasan}

\subsection{Identifikasi Proses Bisnis}

STIKOM Dinamika Bangsa memiliki 3 akvitas utama yaitu Pendidikan dan Pengajaran, Penelitian serta Pengabdian Kepada Mayarakat. Namun pada penelitian ini fokus utamanya adalah Pendidikan dan Pengajaran (Akademik). Proses Bisnis akademik di STIKOM Dinamika Bangsa dapat dilihat pada gambar berikut: 


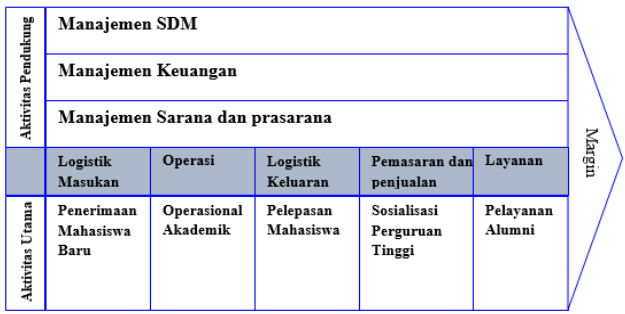

Gambar 2. Model Value Chain bidang akademik STIKOM Dinamika Bangsa

Setelah dilakukan dekomposisi proses bisnis maka selanjutnya dilakukan pemilihan proses bisnis kritis untuk memetakan proses.Dari dekomposisi proses bisnis diatas maka proses bisnis difokuskan pada proses pelayanan administrasi akademik pada seperti pada gambar 3 dimana ada 7 layanan akademik yang berdampak langsung kepada konsumen (mahasiswa) dan jika proses bisnis bisnis ini ditingkatkan akan memberikan dampak langsung STIKOM Dinamika Bangsa.

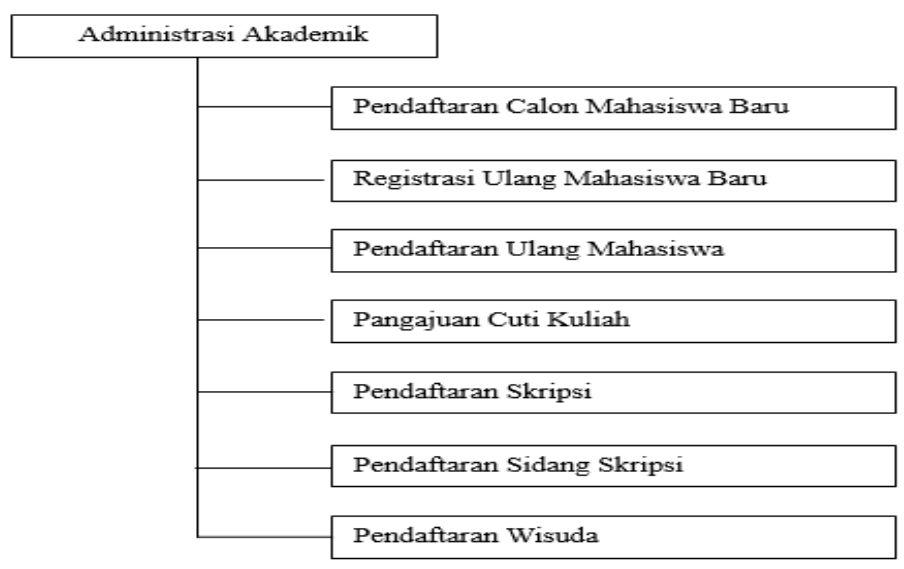

Gambar 3. Pelayanan Administrasi Akademik

\subsection{Pemodelan Proses Bisnis}

Pemodelan Proses Bisnis (PPB) merupakan diagram yang umum mewakili urutan kegiatan secara implisit berfokus pada sebuah proses, tindakan dan kegiatan (job). Tools yang digunakan untuk memodelkan proses bisnis dalam penelitian ini adalah Business Process Modelling Notation (BPMN). Pemodelan ini dilakukan sebelum fase improvment dilaksanaka terhadap proses bisnis yang saat ini sedang berjalan.

\subsubsection{Pendaftaran Calon Mahasiswa Baru}

Pada proses pendaftaran calon mahasiwa baru di STIKOM Dinamika Bangsa melibatkan 3 aktor yaitu calon mahasiswa, bagian pendaftaran (Front Office) dan bagian seleksi. Kendala yang ditemui pada proses bisnis pendaftaran calon mahasiswa ini adalah sebagai berikut:

a. Calon mahasiswa harus datang ke kampus STIKOM Dinamika Bangsa untuk menyerahkan berkas dan uang pendaftaran kebagian Front Office. Untuk calon Mahasiswa yang berdomisili di wilayah kota Jambi mungkin ini tidak menjadi kendala karena bisa diakses dengan waktu yang relatif ingkat. Tapi untuk calon Mahasiswa yang berada diluar kota Jambi tentu ini bisa menjadi kendala karena untuk datang ke kota Jambi membutuhkan waktu yang tidak sebentar. Apa lagi sekarang banyak kompetitor menyerderhanakan proses pendaftaran mahasiswa baru dimana calon mahasiswa tidak perlu harus ke kekampus untuk menyerahkan berkas dan menbayar uang pendaftaran, dimana proses pendaftaran di selesaikan di sistem informasi itu juga. Jika melihat dari data calon mahasiswa baru ditahun 2019 dapat terlihat bahwa calon Mahasiswa dengan jumlah persentase terbesar masih berasal dari kota Jambi dengan persentase sebesar 63\%. Untuk meningkatkan jumlah mahasiswa yang berasal dari luar kota Jambi mungkin salah satu cara dapat dilakukan adalah dengan menyederhanakan proses pendaftaran tersebut.

b. Bagian pendaftaran atau Front Office harus menyimpan berkas pendaftaran dengan jumlah yang cukup banyak setiap tahunnya sehingga volume dokumen kian bertambah. Dengan semakin banyaknya dokumen yang diarsipkan tiap tahun maka tentu kebutuhan untuk penyimpanan dokumen 
nya juga bertambah. Solusi untuk mengatasi ini adalah dengan meniadakan pengumpulan berkas fisik, semua berkas disimpan dalam bentuk digital.

Proses bisnis pendaftaran calon mahasiswa baru di STIKOM Dinamika Bangsa dapat dilihat pada diagram Berikut:

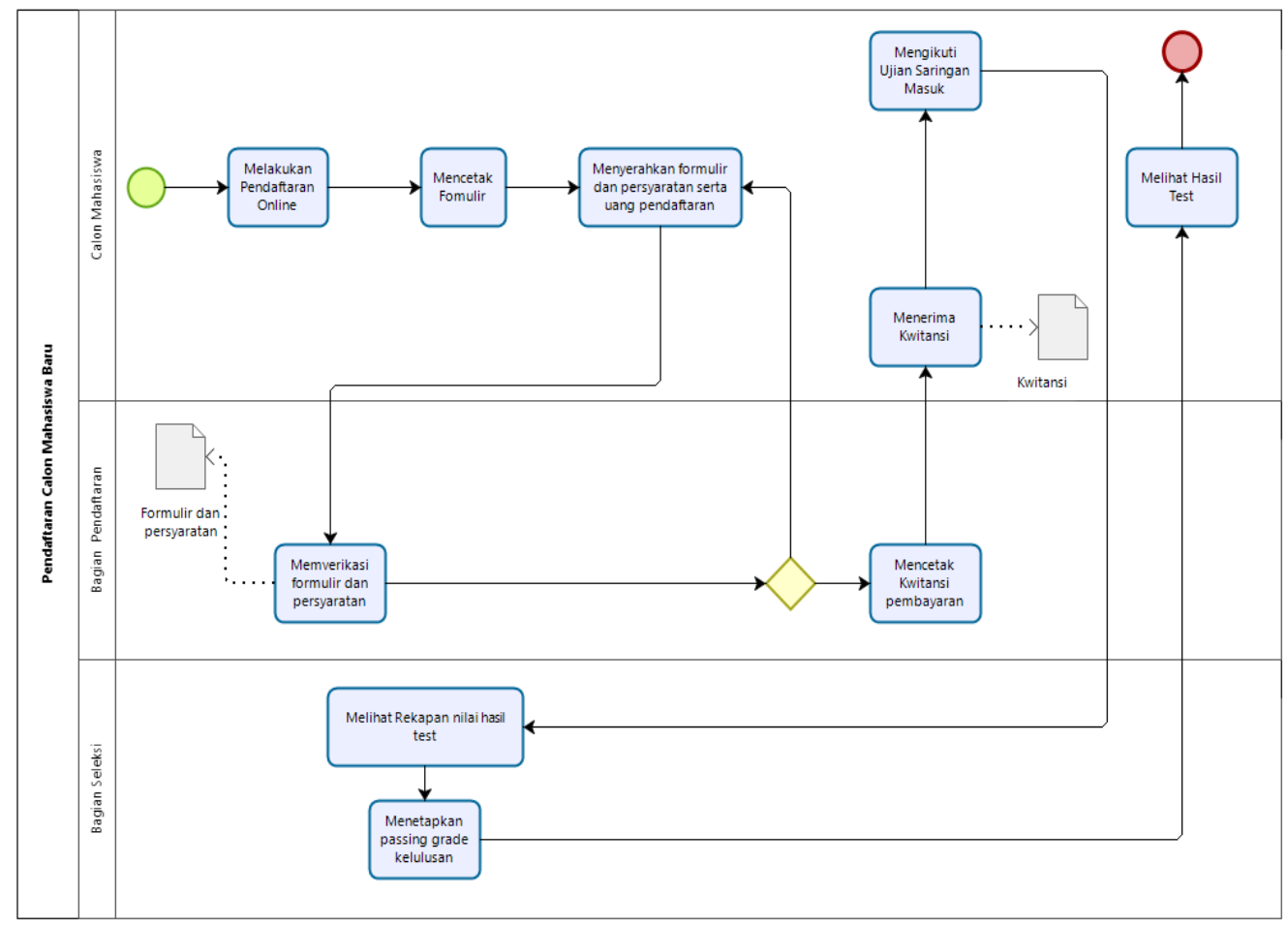

Gambar 4. Proses Bisnis Pendaftaran Calon Mahasiswa Baru

\subsubsection{Registrasi Ulang Mahasiswa Baru}

Pada proses registrasi ulang Mahasiwa Baru terdapat 4 aktor yang terlibat yaitu Mahasiswa, Front Office, BAAK, Dosen PA. Kendala yang ditemui pada proses daftar ulang Mahasiswa baru adalah sebagai berikut:

a. Mahasiswa baru harus datang kekampus untuk menyerahkan formulir registrasi dan persyaratan pendaftaran serta bukti transfer biaya kuliah. Untuk mahasiswa yang berdomisili dikota Jambi ini tidak menjadi masalah, tapi bagi mahasiswa ataupun wali dari mahasiswa yang berasal dari luar kota ini menjadi masalah karena mereka harus kekampus untuk menyerahkan berkas dan bukti tranfer biaya kuliah. Sementara jarak antara daerah dengan kampus cukup jauh.

b. Front office tidak bisa mengecek langsung biaya kuliah yang sudah ditransfer calon mahasiswa baru karena front office hanya menerima bukti tranfer dalam bentuk tunai ataupun struk ATM dari calon mahasiswa baru. Pengecekan bukti transfer dilakukan oleh pihak yayasan. Bahkan kadangkala calon mahasiswa sudah membayar biaya kuliah tapi slip setoran atau bukti transfernya hilang sehingga pihak yayasan butuh waktu yang relatif lama untuk mengecek riwayat transaksi di rekening yayasan.

c. Proses verifikasi KRS berlangsung dua kali, pertama secara online yang kedua secara manual sehingga mahasiswa harus bolak-balik untuk proses verifikasi.

d. Antrian mencetak KRS cukup panjang karena karena ramainya mahasiswa ketika proses kontrak perkuliahan berjalan.

e. Front Office menyimpan salinan KRS yang sangat banyak setiap semesternya sehingga volume salinan file KRS terus bertambah dan ini berdampak ke alokasi tempat penyimpanan file.

Proses bisnis registrasi ulang Mahasiswa baru dapat dilihat pada diagram berikut: 


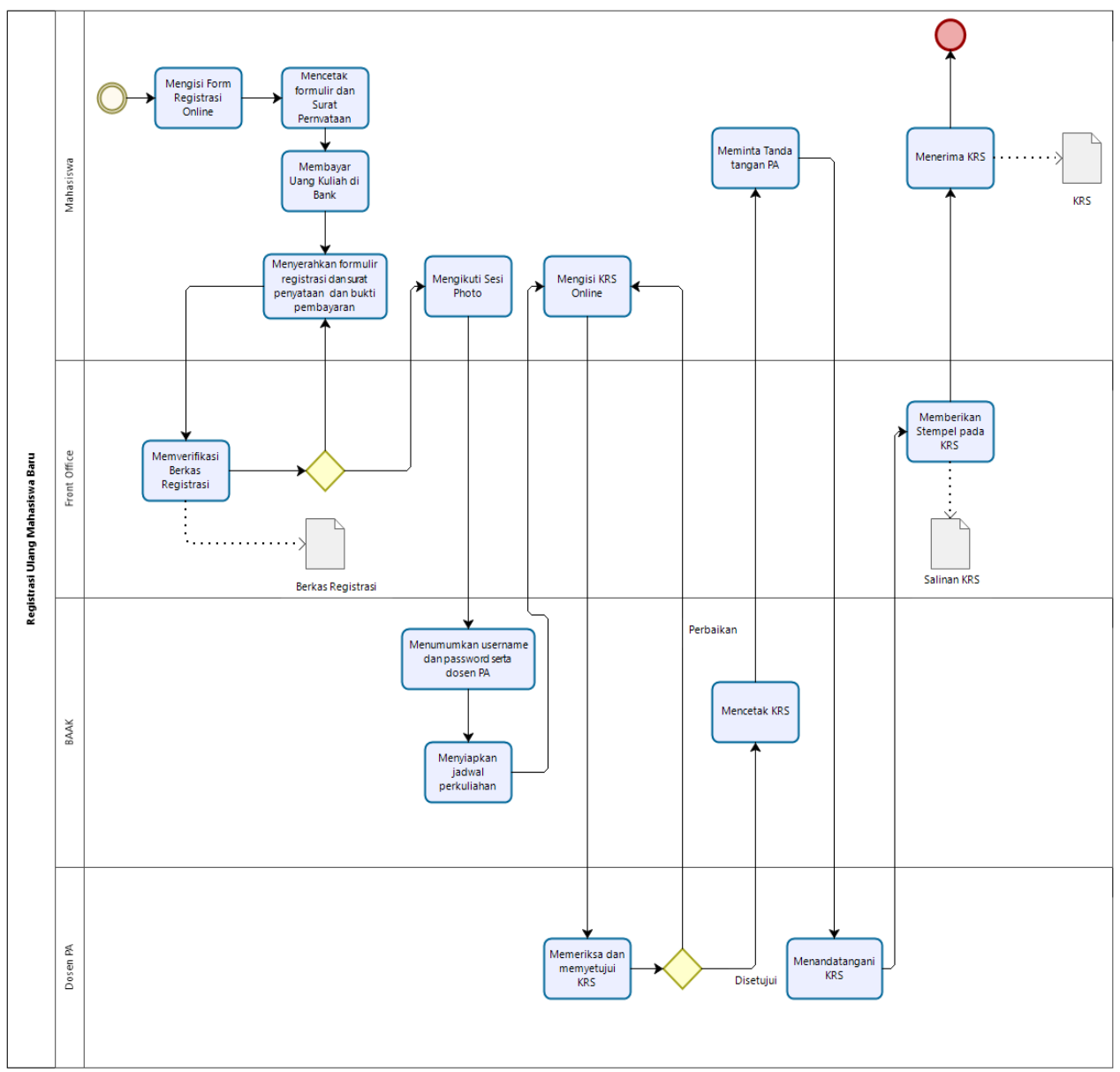

Gambar 5. Proses Bisnis Registrasi Ulang Mahasiswa Baru

\subsubsection{Pendaftaran Ulang Mahasiswa}

Pada proses pendaftaran ulang mahasiswa mahasiswa terdapat 4 aktor yaitu Mahasiswa, Bagian ADM (Front Office), BAAK dan Dosen PA. Pada proses ini pendaftaran ulang Mahasiswa ini terdapat beberapa masalah.

a. Mahasiswa harus datang kekampus menyerahkan bukti tranfer biaya kuliah. Hal ini tentu menjadi kendala bagi Mahasiswa yang berada diluar daerah.

b. Front office tidak bisa mengecek langsung biaya kuliah yang sudah ditransfer mahasiswa karena front office hanya menerima bukti tranfer dalam bentuk tunai ataupun struk ATM dari mahasiswa. Pengecekan transfer dilakukan oleh pihak yayasan.

c. Proses verifikasi KRS saat kontrak perkuliahan berlangsung dua kali, pertama secara online yang kedua secara manual sehingga mahasiswa harus bolak-balik untuk proses verifikasi.

d. Antrian mencetak KRS cukup panjang karena karena ramainya mahasiswa ketika proses kontrak perkuliahan berjalan.

e. Front Office menyimpan salinan KRS yang sangat banyak setiap semesternya sehingga volume salinan file KRS terus bertambah dan ini berdampak ke alokasi tempat penyimpanan file.

Bagi mahasiswa tidak melakukan daftar ulang maka dinyatak non aktif semester tersebut. Proses bisnis untuk pendaftaran ulang mahasiswa dapat dilihat pada diagram berikut: 


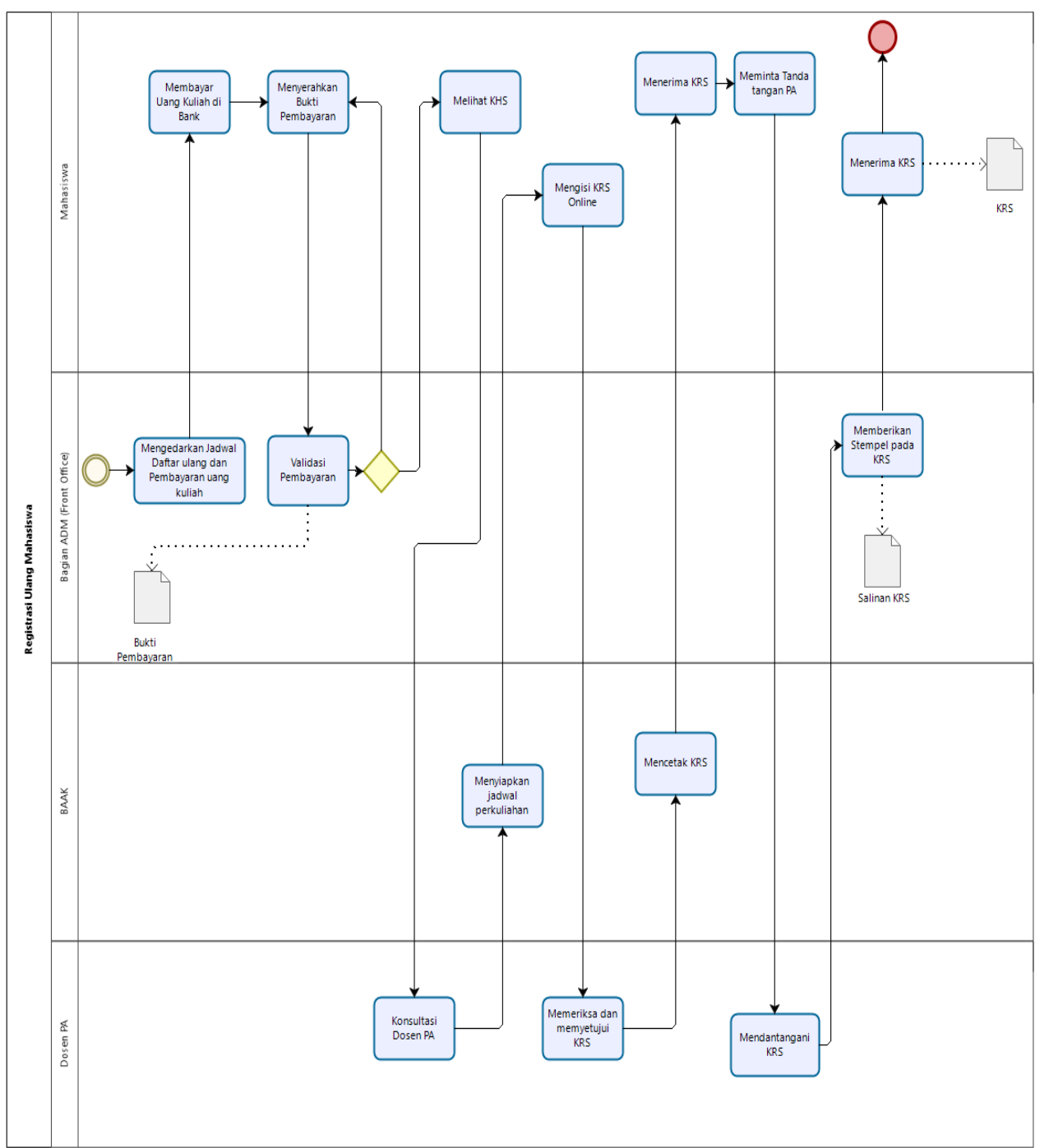

Gambar 6. Proses Pendaftaran Ulang Mahasiswa

\subsubsection{Pendaftaran Cuti Kuliah}

Pada proses pendaftaran ulang mahasiswa mahasiswa terdapat 4 aktor yaitu Mahasiswa, Bagian ADM (Front Office), BAAK dan Dosen PA. Pada proses ini pendaftaran ulang Mahasiswa ini terdapat beberapa masalah.

a. Mahasiswa harus datang kekampus menyerahkan bukti tranfer biaya kuliah. Hal ini tentu menjadi kendala bagi Mahasiswa yang berada diluar daerah.

b. Front office tidak bisa mengecek langsung biaya kuliah yang sudah ditransfer mahasiswa karena front office hanya menerima bukti tranfer dalam bentuk tunai ataupun struk ATM dari mahasiswa. Pengecekan transfer dilakukan oleh pihak yayasan.

c. Proses verifikasi KRS saat kontrak perkuliahan berlangsung dua kali, pertama secara online yang kedua secara manual sehingga mahasiswa harus bolak-balik untuk proses verifikasi.

d. Antrian mencetak KRS cukup panjang karena karena ramainya mahasiswa ketika proses kontrak perkuliahan berjalan.

e. Front Office menyimpan salinan KRS yang sangat banyak setiap semesternya sehingga volume salinan file KRS terus bertambah dan ini berdampak ke alokasi tempat penyimpanan file.

Adapun proses bisnis cuti kuliah di STIKOM Dinamika Bangsa dapat dilihat pada diagram berikut: 


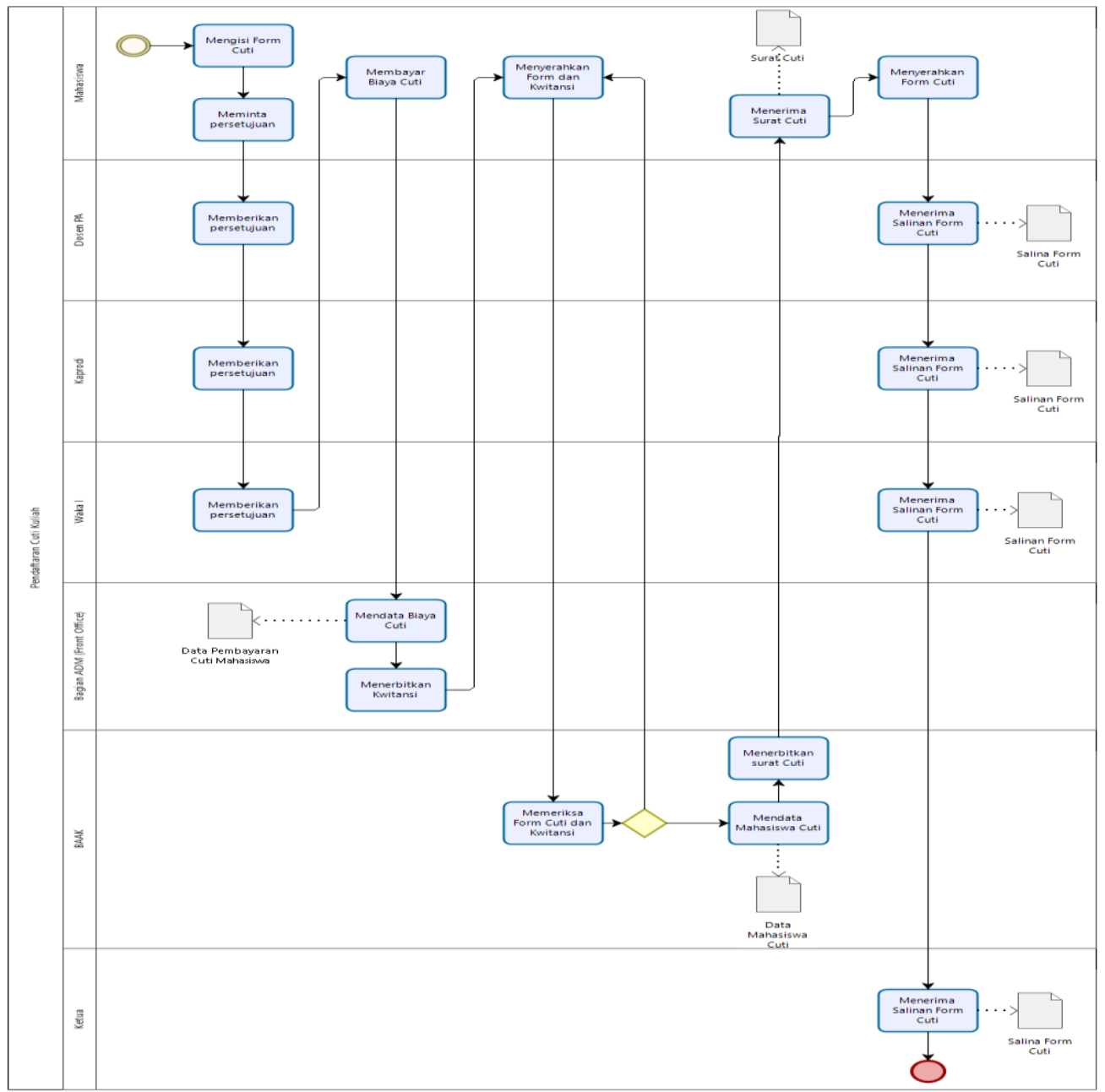

Gambar 7. Proses Pendaftaran Cuti Kuliah

\subsubsection{Pendaftaran Skripsi}

Pada proses pendaftaran Skripsi terdapat 6 aktor yang terlibat yaitu Mahasiswa, Front Office, Staf Prodi, Kaprodi, Wakil Ketua I dan Ketua. Permasalahan yang muncul pada proses pendaftaran Skripsi ini adalah sebagai berikut:

a. Front Office tidak bisa mengecek langsung bukti transfer biaya Skripsi yang dilakukan Mahasiswa.

b. Staf prodi butuh waktu untuk mendata proposal yang masuk sementara jarak pengumpulan proposal dengan penyusunan dan pengumuman jadwal serta pelaksanaan sidang sangat pendek.

c. Masih ada mahasiswa yang tidak mengikuti seminar proposal karena mereka salah atau tidak mengetahui jadwal seminar mereka.

d. Staf prodi juga butuh waktu untuk mendata proposal yang diterima atau ditolak serta judul proposal yang telah di setujui perbaikannya oleh reviewer.

Pendaftararan Skripsi dilakukan oleh Mahasiswa-Mahasiswa yang sudah memenuhi persyaratan untuk mengontrak Skripsi. adapun persyaratan untuk mengontrak Skripsi adalah sudah lulus matakuliah sebanyak 124 SKS, nilai D/D+ tidak lebih dari 6 SKS, mengontrak Matakuliah Kerja Praktek serta IPK $>=2$ serta sudah membayar biaya Skripsi. Proses bisnis pendaftaran skripsi dapat dilihat pada diagram berikut : 


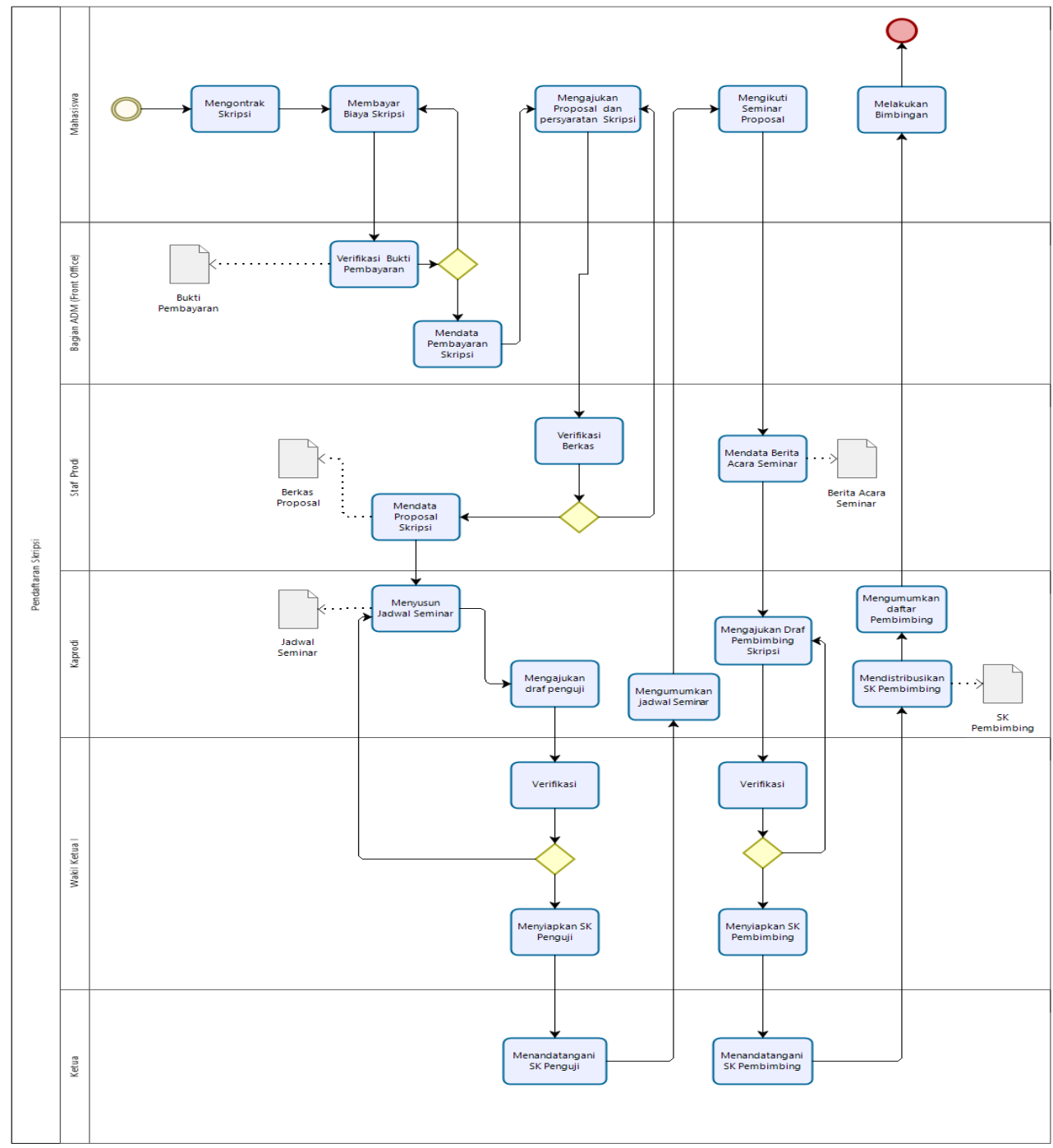

Gambar 8. Proses Pendaftaran Skripsi

\subsubsection{Pendaftaran Ujian Labor dan Sidang Skripsi}

Proses pendaftaran ujian labor dan sidang Skripsi dilakukan oleh para Mahasiswa yang telah memenuhi syarat untuk mengikuti sidang skripsi. Adapun persyaratanya yaitu sudah lulus semua matakuliah, nilai D atau D+ maksimal 6 SKS, sudah mengambil 6 matakuliah pilihan. Setelah memenuhi persyaratan tersebut maka mahasiswa bisa mendaftar untuk mengikuti ujian labor dan sidang skripsi. Mahasiswa terlebih dahulu mengikuti ujian labor, jika dinyatakan lulus selanjutnya akan dijadwalkan untuk mengikuti sidang skripsi.

Pada proses pendaftaran sidang skripsi ada lima aktor yang terlibat yaitu Mahasiswa, Staf Prodi, Kaprodi, Waka I dan Ketua. Permasalahan yang muncul pada proses sidang skripsi yaitu:

a. Masih ada Mahasiswa yang sudah mendaftarkan diri untuk mengikuti ujian labor dan sidang Skripsi bahkan ada yang sudah mengikuti sidang tapi ternyata tidak memenuhi syarat SKS atau matakuliah yang disyaratkan sehingga hasil sidang mahasiswa tersebut dinyatakan batal dan mahasiswa tersebut wajib meyelesaikan persyaratan matakuliah yang belum tuntas serta mengikuti sidang ulang.

b. Masih ada mahasiswa yang tidak mengikuti sidang dikarenakan salah melihat jadwal atau tidak tahu jadwal sidang skripsinya sehingga pihak akademik terpaksa menjadwalkan ulang sidang skripsinya. 
Proses bisnis pendaftaran ujian labor dan sidang skripsi dapat dilihat pada diagram berikut:

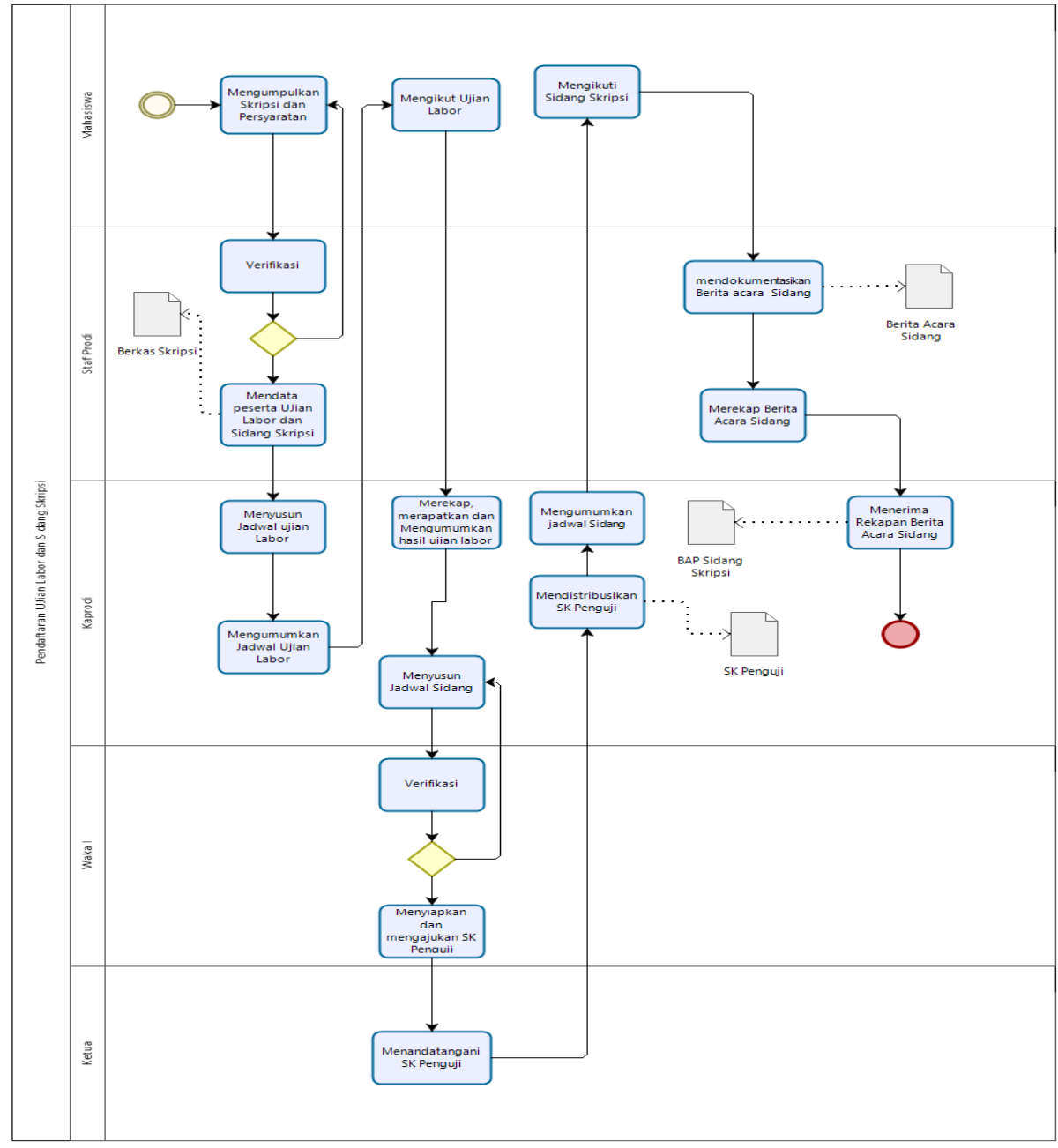

Gambar 9. Proses Pendaftaran Sidang Skripsi

\subsubsection{Pendaftaran Wisuda}

Pendaftaran wisuda dilakukan oleh mahasiswa-mahasiswa yang sudah dinyatakan lulus. Mahasiswa yang dinyatakan lulus selanjutnya melakukan pendaftaran dan mengunggah persyaratan-persyaratan secara online, isian tersebut nantinya akan diverifikasi oleh BAAK untuk penerbitan ijazah, transkrip dan SKPI (Surat Keterangan Pedamping Ijazah). Setelah melakukan pendaftaran mahasiswa wajib membayar biaya wisuda, membayar sumbangan perpustakaan serta mengurus bebas biaya ADM. Semua persyaratan tersebut diserahkan ke Staff Prodi, staf prodi akan memverifikasi semua berkas yang diserahkan, setelah lengkap maka mahasiswa akan diperkenankan untuk mengikuti kegiatan wisuda sesuai dengan jadwal yang telah di tetapkan. Pada proses pendaftaran wisuda ada enam aktor yang terlibat yaitu Mahasiswa, BAAK, Front Office, Perpustakaan, Waka II, Staf Prodi. Pada proses pendaftaran wisuda ini terdapat beberapa masalah yaitu:

a. Masih ada kesalahan atau perbedaan dalam penulisan biodata oleh mahasiswa (Nama, tempat Lahir ,tanggal lahir) sehingga kadangkala setelah ijazah, transkrip dan SKPI diterbitkak pihak BAAK mesti mencetak ulang lagi untuk perbaikan datanya.

b. Verikasi pembayaran wisuda hanya dilakukan melalui bukti setoran ke bank dan pihak front Office tidak bisa mengecek secara langsung pembayaran yang sudah masuk, pengecekan biasanya dilakukan oleh pihak yayasan.

c. Banyaknya berkas yang berkaitan dengan keuangan yang mesti dilengkapi dan di urus oleh mahasiswa seperti bukti pembayaran wisuda, bukti sumbangan perpustakaan, bukti bebas ADM.

d. Staf Prodi mesti memvalidasi satu persatu satu berkas fisik yang diserahkan oleh Mahasiswa. 


\subsection{Analisis Aktivitas dan Usulan Perbaikan Proses Bisnis}

Setelah dilakukan pemodelan terhadap proses bisnis yang saat ini berjalan selanjutnya dilakukan analasis value added. Analisis ini mengklasifikan aktivitas kedalam tiga klasifikasi yaitu Real Value Added (RVA) merupakanaktivitas yang mempunyai nilai langsung terhadap konsumen, Business Value Added (BVA) aktivitasyang tidak memiliki nilai langsung terhadap konsumen namun diperlukan untuk proses bisnis dan Non Value Added (NVA) aktivitasyang tidak mempunyai nilai tambah baik kepada pelanggan maupun dalam proses bisnis. Pada analisis ini dipetakan nama aktivitas, aktor, klasifikasi dan rencana perbaikan untuk masing-masing aktivitas pada proses bisnis. Berikut hasil analisis aktivitas dan usulan perbaikan proses bisnis:

a. Proses bisnis pendaftaran calon Mahasiswa baru

b. Proses bisnis pendaftaran calon mahasiswa baru memiliki 10 aktivitas yang terdiri 6 berklasifikasi RVA, 3 Berklasifikasi BVA dan 1 berklasifikasi NVA. Dari total 6 RVA terdapat terdapat dua aktivas yang diusulkan untuk perbaikan proses, sedangkan dari total 3 aktivitas BVA terdapat 1 aktivitas yang diusulkan untuk perbaikan proses dan terdapat 1 aktivitas NVA yang di eleminasi

c. Proses registrasi ulang mahasiswa baru

d. Aktivitas NVA. Dari analisis terdapat 4 aktivas NVA yang di eliminasi untuk menyederhanakan birokrasi, 3 aktivitas RVA yang mengalami perbaikan proses serta 1 aktivitas BVA yang mengalami perbaikan proses.

e. Proses pendaftaran ulang Mahasiswa

f. Pada proses pendaftaran ulang Mahasiswa terdapat 15 aktivitas dengan rincian 6 aktivitas RVA, 2 aktivitas BVA dan 7 aktivitas NVA. Dari analisis terdapat 7 aktivitas NVA di eliminasi untuk menyederhanakan proses serta 2 aktivitas mengalami perbaikan yang terdiri dari 2 aktitivas RVA.

g. Proses bisnis cuti kuliah

h. Pada proses bisnis cuti kuliah terdapat 18 aktivitas yang terdiri dari 6 akvitas RVA, 3 Aktivitas BVA dan 9 aktivitas NVA. Dari analisis ini berarti terdapat 9 aktivitas NVA yang di eliminasi serta terdapat 8 aktivitas yang mengalami perbaikan untuk meningkatkan layanan yang terdiri dari 5 aktivitas RVA dan 3 Aktivitas BVA.

i. Proses Bisnis Pendaftaran Skripsi

j. Proses Bisnis Pendaftaran Skripsi memilki 22 aktivitas yang terdiri dari 5 aktivitas RVA, 16 aktivitas BVA dan 1 Aktivitas NVA. Dari analisis ini terdapat 6 aktivitas yang mengalami perbaikan proses yang terdiri dari aktivitas RVA dan 4 akvitas BVA serta ada 1 akvitas NVA yang di eliminasi.

k. Proses bisnis pendaftaran sidang

1. Pada proses bisnis pendaftaran sidang terdapat 13 aktivitas yang terdiri dari 3 aktivitas RVA, 9 Aktivitas BVA dan 1 Aktivitas NVA. Dari analisis ini terdapat 5 aktivitas yang di upgrading yang terdiri 2 aktivitas RVA dan 3 aktivitas BVA. Sedangkan yang di eliminasi ada 1 aktivitas NVA.

m. Proses Pendaftaran Wisuda

n. Proses Pendaftaran Wisuda memiliki 19 aktivitas dengan rincian 5 aktivitas RVA, 8 aktivitas BVA dan 6 aktivitas NVA. Pada proses bisnis pedaftaran wisuda ini terdapat 6 aktivitas yang di eliminasi, 8 aktivitas yang mengalami perbaikan yang terdiri dari 5 aktivitas RVA dan 3 aktivitas BVA.

\subsection{Pemodelan Rekomendasi Proses Bisnis}

Setelah dilakukan analis permasalahan dan rekomendasi perbaikan terhadap proses bisnis yang ada, berikut ini merupakan usulan diagram perbaikan terhadap proses bisnis pelayanan akademik di STIKOM Dinamika Bangsa.

\subsubsection{Rekomendasi perbaikan proses bisnis Pendaftaran Calon Mahasiswa Baru}

Usulan perbaikan proses bisnis pendaftaran calon mahasiswa baru itu terjadi pada aktivitas menyerahkan formulir dan persyaratan serta uang pendaftaran di kampus, verifikasi berkas, mencetak kwitansi dan menerima kwitansi. Rekomendasi perbaikan proses bisnis Pendaftaran Calon Mahasiswa Baru dapat dilihat pada diagram berikut: 


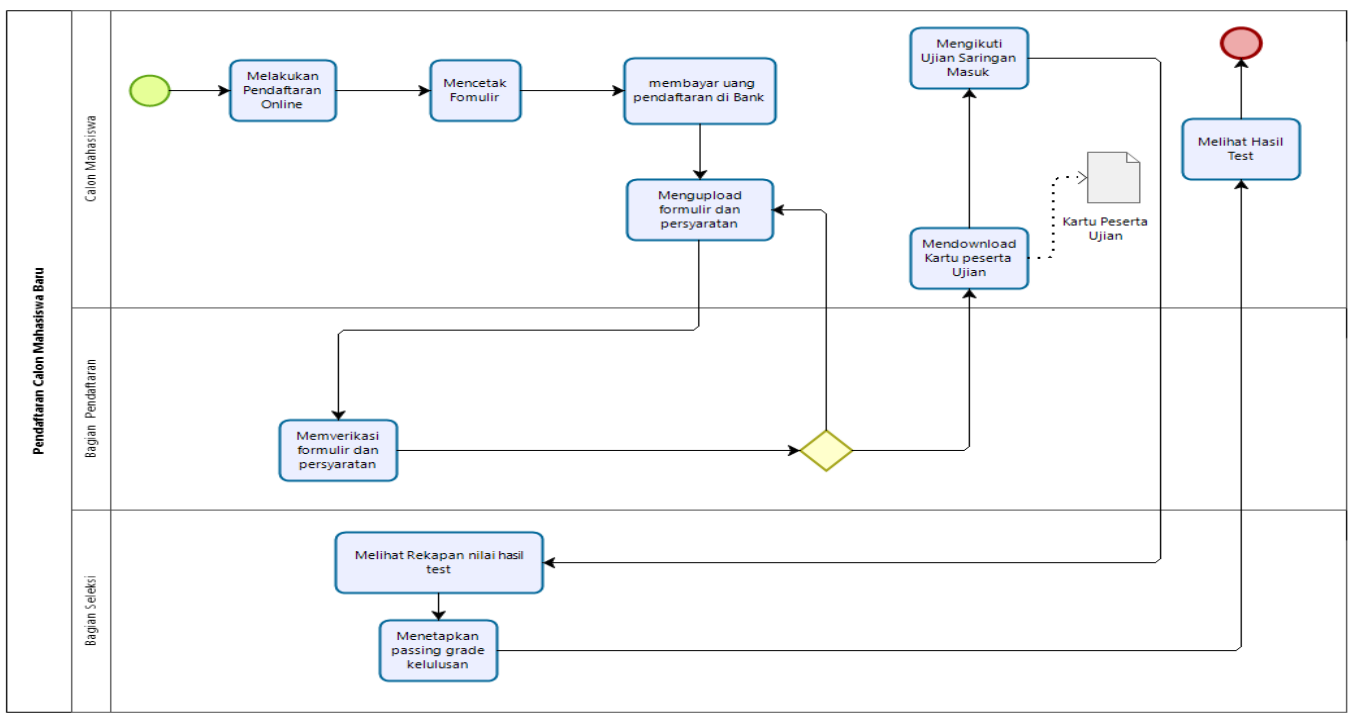

Gambar 10. Rekomendasi Proses Bisnis Pendaftaran Calon Mahasiswa Baru

\subsubsection{Rekomendasi perbaikan Proses Bisnis Registrasi Ulang Mahasiswa Baru}

Rekomendasi atau usulan perbaikan proses bisnis Registrasi ulang Mahasiswa Baru terdapat pada aktivitas membayar uang kuliah, menyerahkan formulir dan persyaratan, Verifikasi Berkas, mencetak KRS, Menandatangani KRS, memberikan stempel pada KRS dan menerima KRS. Rekomendasi perbaikan Proses Bisnis Registrasi Ulang Mahasiswa Baru dapat dilihat pada diagram berikut:

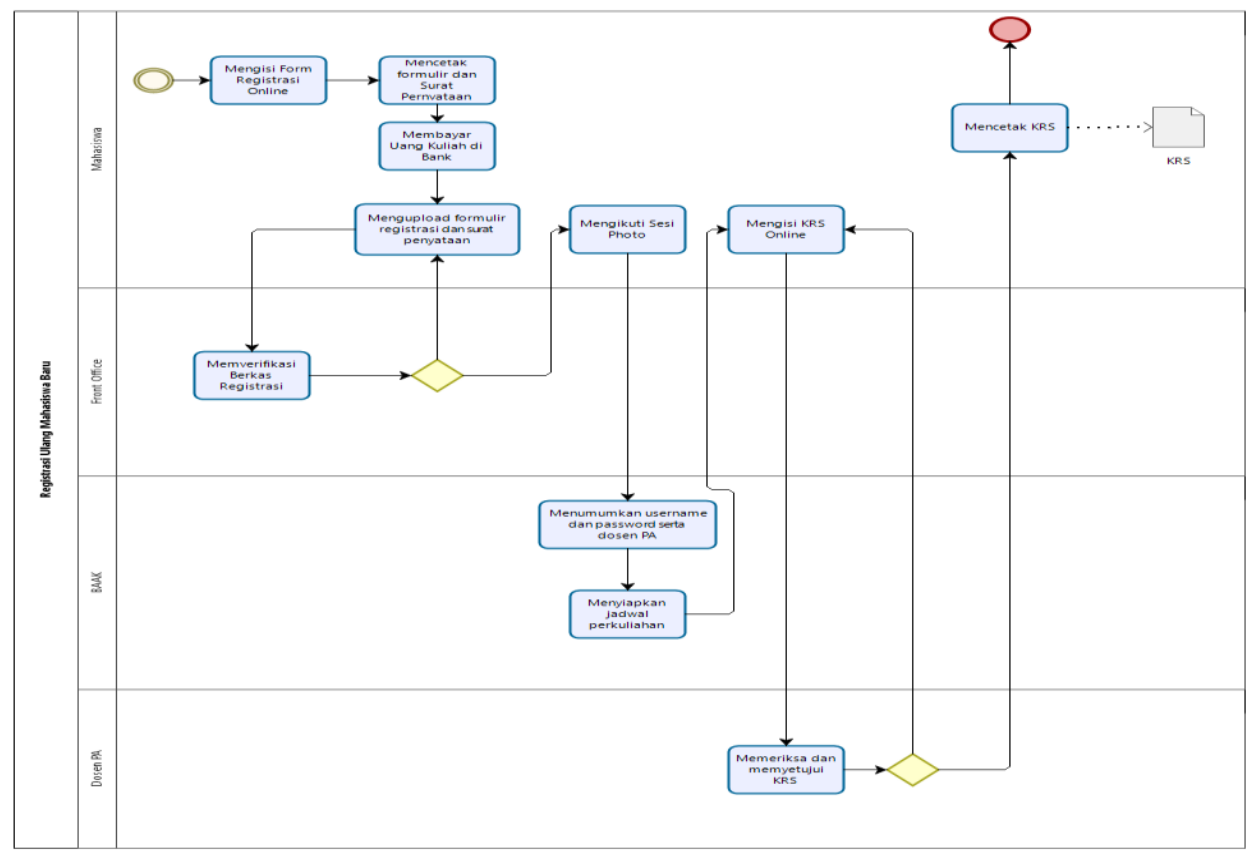

Gambar 11. Rekomendasi perbaikan Proses Bisnis Registrasi Ulang Mahasiswa Baru

\subsubsection{Rekomendasi proses bisnis Pendaftaran Ulang Mahasiswa}

Rekomendasi atau usulan perbaikan pada proses bisnis pendaftaran ulang Mahasiswa terdapat pada aktivitas membayar uang kuliah, menyerahkan bukti pembayaran, validasi bukti pembayaran, mencetak KRS, menerima KRS, Meminta tanda tangan KRS, menandatangani KRS serta memberikan Stempel pada KRS. Rekomendasi atau usulan perbaikan proses bisnis pendaftaran ulang Mahasiswa dapat dilihat pada gambar berikut: 


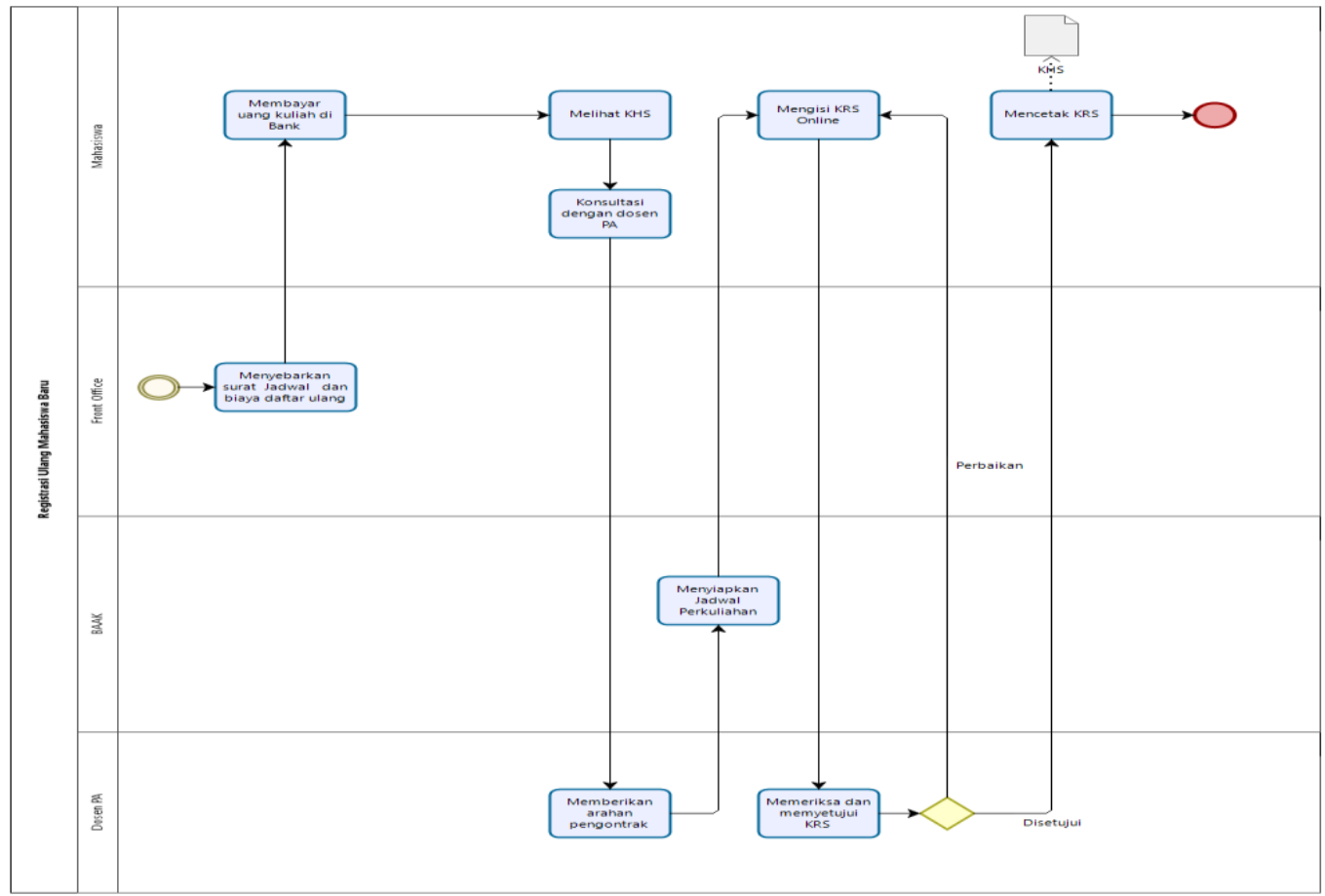

Gambar 12. Rekomendasi proses bisnis Pendaftaran Ulang Mahasiswa

\subsubsection{Rekomendasi proses bisnis Cuti Kuliah}

Rekomendasi perbaikan proses bisnis cuti kuliah terdapat pada aktivitas pengisian form cuti, meminta persetujuan Waka I, membayar biaya cuti, mendata biaya cuti, menerbitkan kwitansi, menyerahkan Form dan kwitansi, menerbitkan surat cuti, menerima surat cuti, menyerahkan form cuti. Rekomendasi proses bisnis untuk cuti kuliah dapat dilihat pada gambar berikut:

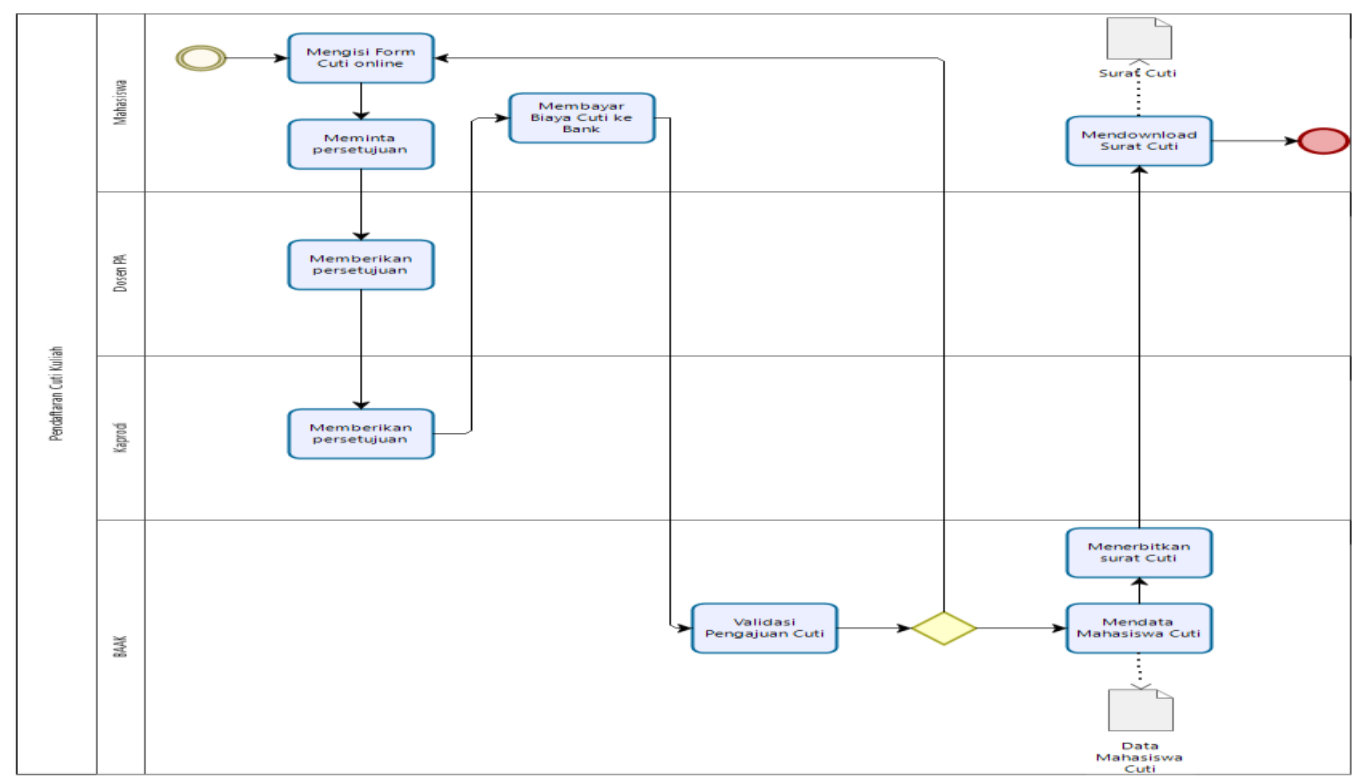

Gambar 13. Rekomendasi Proses Bisnis Cuti Kuliah 


\subsubsection{Rekomendasi Proses Bisnis pendaftaran Skripsi}

Rekomendasi atau usulan perbaikan proses bisnis pendaftaran Skripsi terjadi pada aktivitas pengajuan proposal, membayar skripsi, verifikasi pembayaran, pendataan proposal, pengumuman jadwal, mendata berita acara seminar. Rekomendasi pendaftaran Skripsi dapat dilihat pada gambar berikut:

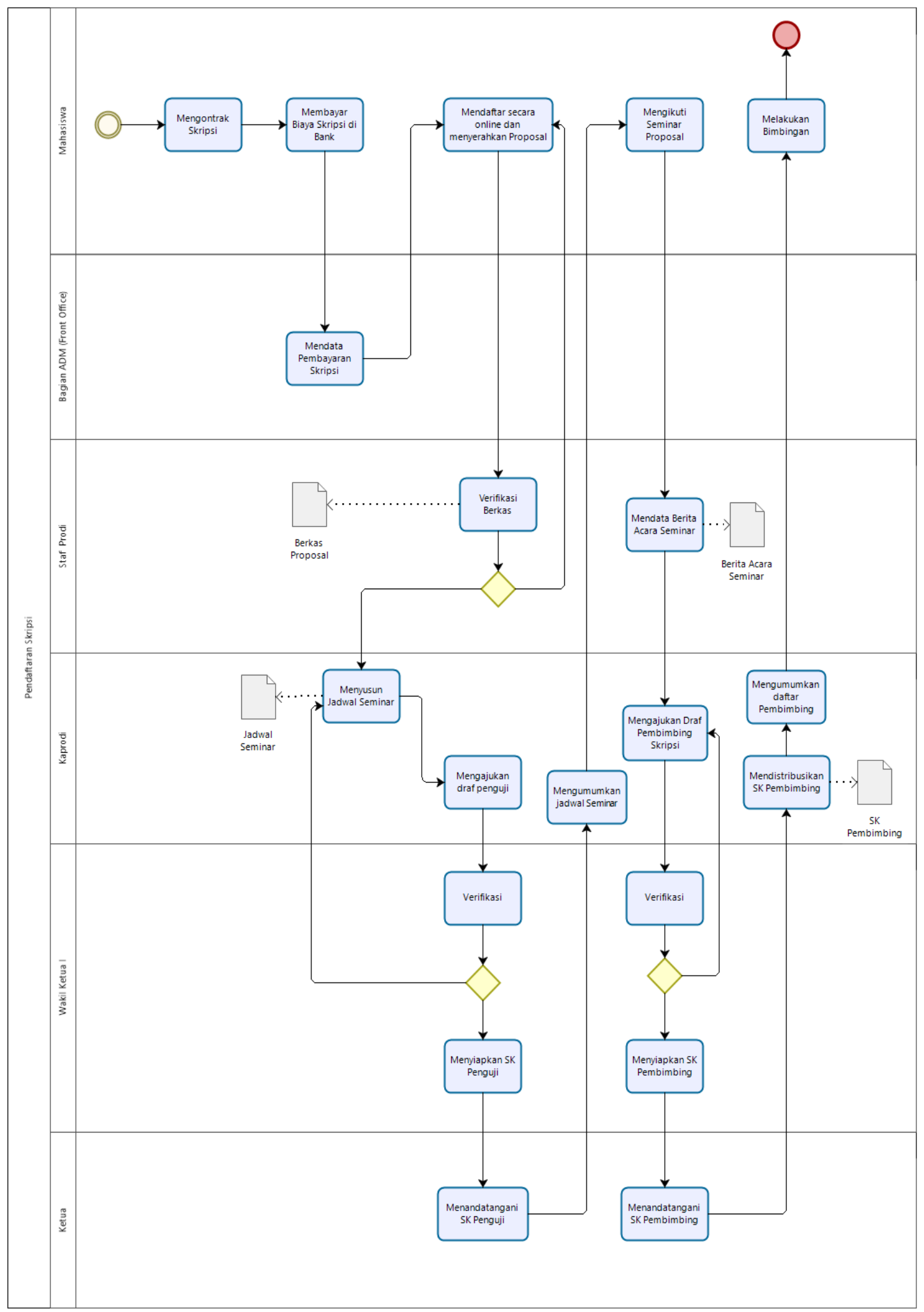

Gambar14. Rekomendasi Pendaftaran Skripsi 


\subsubsection{Rekomendasi Proses Bisnis Pendaftaran Ujian Labor dan Sidang Skripsi}

Rekomendasi atau usulan perbaikan proses bisnis pendaftaran ujian labor dan sidang skripsi terjadi pada aktivitas mengumpulkan skripsi dan persyaratan, verifikasi berkas, mendata peserta, mengumumkan jadwal sidang.

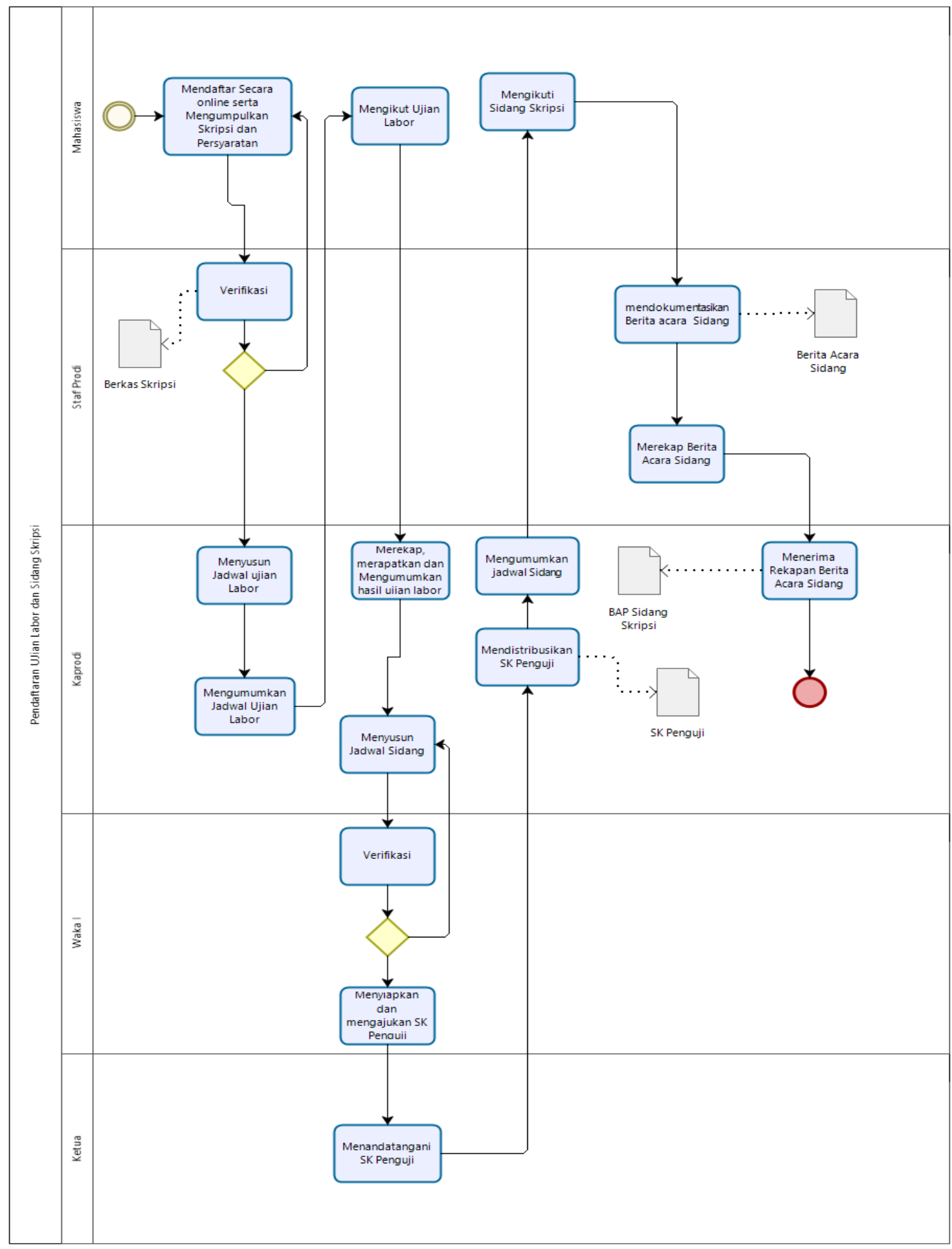

Gambar15. Rekomendasi proses Bisnis pendaftaran ujian labor dan sidang skripsi 


\subsubsection{Rekomendasi Proses Bisnis Pendaftaran Wisuda}

Rekomendasi proses bisnis pendaftaran wisuda terdapat pada aktivitas pendaftaran online, verifikasi berkas wisuda, pembayaran biaya wisuda, pembayaran sumbangan perpustakaan, pengurusan surat bebas ADM. Rekomendasi proses bisnis pendaftaran Wisuda dapat dilihat pada diagram berikut:

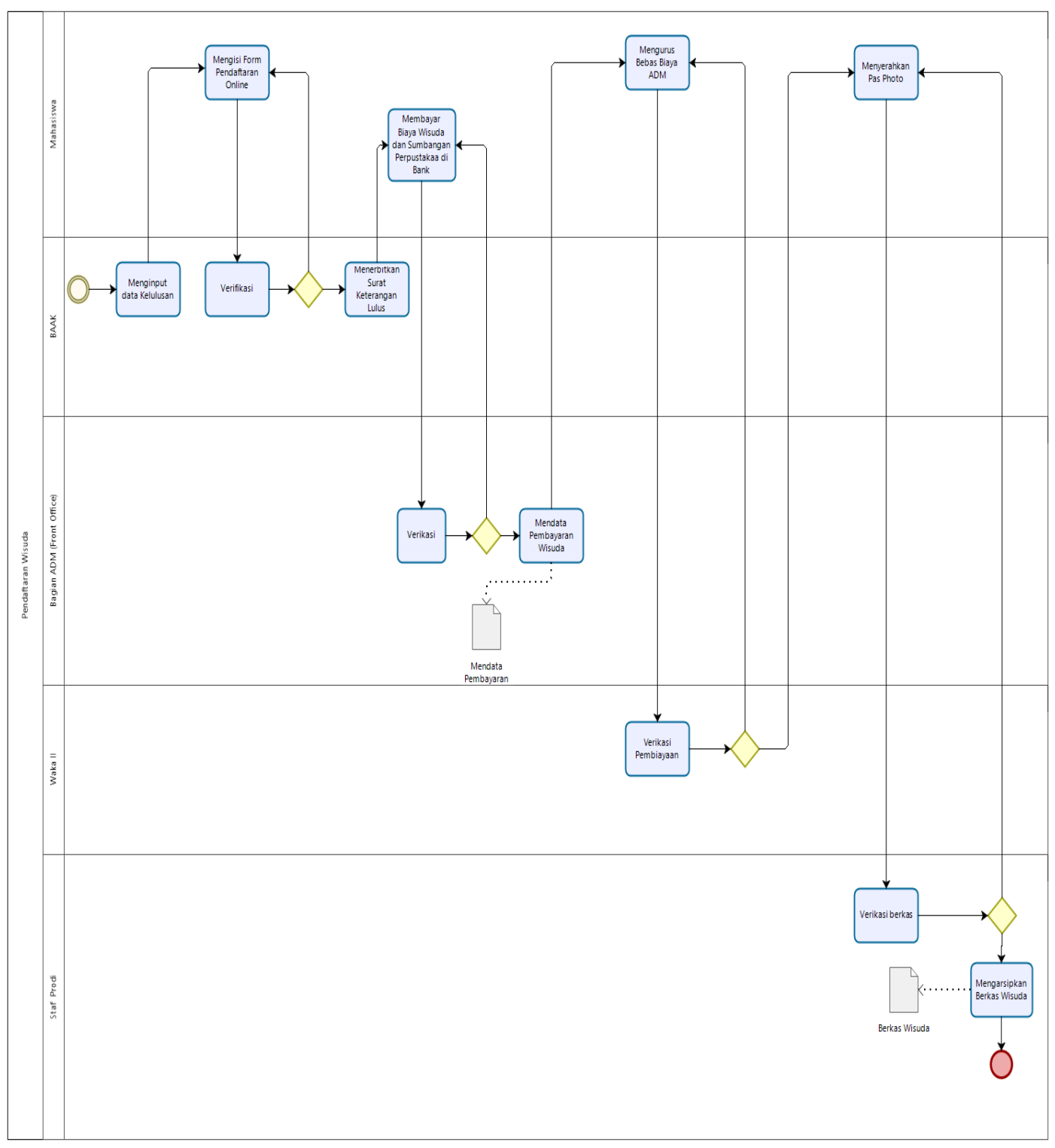

Gambar16. Rekomendasi proses Bisnis Pendaftaran Wisuda

\subsection{Perbandingan jumlah aktivitas proses bisnis As Is dan To Be}

Setelah dilakukan pemodelan dan analisis value added untuk memetakan aktivitas apa saja yang dieliminasi dan di upgradeterhadap proses bisnis yang saat ini (as is)dimana dari hasil analisis tersebut terdapat beberapa aktivitas yang dieliminasi dan di upgrade sehingga jumlah aktivitas pada proses bisnis yang direkomendasikan jumlahnya lebih sedikit. Perbandingan Jumlah aktivitas yang direkomendasikan. seperti terlihat pada table berikut: 
Tabel 1. Perbandingan Jumlah Aktivitas Proses Bisnis As is dan To Be

\begin{tabular}{lcc}
\hline \multirow{2}{*}{ Proses Bisnis } & \multicolumn{2}{c}{ Jumlah Aktivitas } \\
\cline { 2 - 3 } & As Is & To Be \\
\hline Pendaftaran Calon Mahasiswa Baru & 10 & 10 \\
Registrasi Ulang Mahasiswa Baru & 15 & 11 \\
Pendaftaran Ulang Mahasiswa & 15 & 8 \\
Pengajuan Cuti Kuliah & 18 & 9 \\
Pendaftaran Skripsi & 22 & 21 \\
Pendaftaran Sidang Skripsi & 13 & 12 \\
Pendaftaran Wisuda & 19 & 13 \\
\hline
\end{tabular}

\section{Kesimpulan}

Dari hasil pembahasan diatas maka dapat disimpulkan terdapattotal 35 aktivitas dalam proses bisnis yang direkomendasikan di upgrade atau diperbaiki serta terdapat total 28 aktivitas yang dieliminasi dari proses bisnis akademik proses bisnis sehingga efisiensi dan efektivitas proses bisnis dapat ditingkakan. Untuk penelitian berikutnya bisa dilanjutkan ke evaluasi dan pemodelan pada proses bisnis kegiatan penelitian dan pengabdian kepada masyarakat.

\section{Daftar Rujukan}

[1] R. Yunitarini and F. Hastarita, "Pemodelan Proses Bisnis Akademik Teknik Informatika Universitas Trunojouo dengan Business Process Modelling Notation (BPMN)," SimanteC, vol. 5, no. 2, pp. $93-$ $100,2016$.

[2] M. A. Ramdhani, "Pemodelan Proses Bisnis Sistem Akademik Menggunakan Pendekatan Business Process Modelling Notation (Bpmn) (Studi Kasus Institusi Perguruan Tinggi Xyz)," J. Inf., vol. 7, no. 2, p. 2, 2015.

[3] A. T. Helmi, I. Aknuranda, and M. C. Saputra, "Analisis Dan Pemodelan Proses Bisnis Menggunakan Business Process Improvement (BPI) Pada Lembaga Bimbingan Belajar (Studi Kasus: Lembaga Bimbingan Belajar Prisma)," J. Pengemb. Teknol. Inf. dan Ilmu Komput. Univ. Brawijaya, vol. 2, no. 10, 2018.

[4] I. Ismanto, F. Hidayah, and K. Kristinanti, "Pemodelan Proses Bisnis Sistem Akademik Menggunakan Pendekatan Business Process Modelling Notation (BPMN)," J. Inf., vol. 7, no. 2, pp. $1-8,2016$.

[5] T. Susanto, D. Pramono, N. Y. Setiawan, "Analisis Dan Perbaikan Proses Bisnis Menggunakan Metode Business Process Improvement (BPI) ( Studi Kasus : PT . Wonojati Wijoyo )," J. Pengemb. Teknol. Inf. dan Ilmu Komput., vol. 2, no. 12, pp. 6201-6209, 2018.

[6] M. Reza, Y. Rohayati, and S. Wulandari, "Perbaikan Proses Bisnis Pada Usaha Kecil Menengah Nutrity Menggunakan Metode Business Process Improvement," eProceedings Eng., vol. 2, no. 2, pp. 4361-4366, 2015.

[7] C. Ramadhana and E. Chandra, "Peningkatan Proses Bisnis Kegiatan Carry Over pada Politeknik Caltex Riau," J. Komput. Terap., vol. 5, no. 2, pp. 22-31, 2019.

[8] F. I. Achmad, Rispianda, and G. P. Liansari, "Business Process Improvement Untuk Proses Penjualan , Produksi Dan Pembelian di CV. Cahaya Abadi Teknik," J. Online Inst. Teknol. Nas., vol. 4, no. 01, pp. 382-393, 2016.

[9] S. Harjanto and S. Setiyowati, "Pemodelan Proses Bisnis Manajemen Aset Menggunakan Togaf Architecture Development Method Studi Kasus: STMIK XYZ Surakarta," J. Ilm. SINUS, vol. 16, no. 2, pp. 63-70, 2018.

[10] N. D. Yohana and F. Marisa, "Perancangan Proses Bisnis Sistem Human Resource Management (HRM) Untuk Meningkatkan Kinerja Pegawai," J I M P - J. Inform. Merdeka Pasuruan, vol. 3, no. 2, pp. 23-32, 2018. 